California cases on blasting, ${ }^{73}$ storage $^{74}$ or manufacture ${ }^{75}$ of explosives, and escape of artificially collected water. ${ }^{76}$

Robert W. James

\title{
LIMITATIONS TO SETTLORS' HEIRS
}

\section{Introduction}

When a settlor transfers property in trust for the benefit of himself (or a third person) for life, and in terms limits a remainder to his heirs or next-of-kin, does the limitation create in such heirs or next-of-kin an interest as purchasers-i.e., a true remainder-or merely leave a reversion in the settlor? Opinions of courts, and of text writers, diverge upon this question; despite recent pronouncements by the California Supreme Court in Bixby v. California Trust Co. ${ }^{1}$ and the New York Court of Appeals in Richardson v. Richardson, ${ }^{2}$ important problems remain unsettled.

The inquiry is essentially one as to who-the settlor or his heirsowns the equitable future interest. The question arises in the situations described below:

(1) Where the settlor subsequent to creation of the trust attempts to alienate, devise or bequeath this future interest. ${ }^{3}$

(2) Where creditors of the settlor or of the heirs presumptive seek to reach their respective interests in the trust estate. ${ }^{4}$

73 Munro v. Dredging etc. Co. (1890) 84 Cal. 515, 24 Pac. 303 (absolute liability for blasting in a populated area); Colton v. Onderdonk (1886) $69 \mathrm{Cal} .155,10 \mathrm{Pac} .395$ (absolute liability for blasting in populated area); McGrath v. Basich Bros. Const. Co. (1935) 7 Cal. App. (2d) 573, 46 P. (2d) 981 (absolute liability for vibration from blasting, under doctrine of Green v. General Petroleum Corp., supra note 11 ; McKenna v. Pacific Electric Ry. Co. (1930) 104 Cal. App. 538, 268 Pac. 445, (1930) 19 Calrf. L. REv. 94 (absolute liability for vibration from blasting in a populated area). Compare, Houghton v. Loma Prieta Lumber Co. (1907) 152 Cal. 500, 93 Pac. 82 (defendant not absolutely liable for blasting by his independent contractor in an isolated area).

74 Kleebauer v. Western Fuse etc. Co., supra note 70; Fisber v. Western Fuse etc. Co. (1910) 12 Cal. App. 739, 108 Pac. 569. Although neither case expressly discussed absolute liability, both refused to declare the storage of explosives a nuisance per se.

75 Judson v. Giant Powder, supra note 34 (applied res ipsa loquitur).

70 Rozewski v. Simpson, supra note 49 (left open the question of absolute liability) ; Sutliff v. Sweetwater Water Co., supra note 70 (disapproved of Rylands v. Fletcher, but perliaps dictum only) ; Parker v. Larsen (1890) 86 Cal. 236, 24 Pac. 989 (held defendant absolutely liable, but may have involved a nuisance); Curci v. Palo Verde Irr. Dist. (1945) 69 Cal. App. (2d) 583, 159 P. (2d) 674; Nola v. Orlando, supra note 70, (imposed absolute liability, but may bave involved a nuisance); Kall v. Carruthers, supra note 70 (imposed absolute liability, but seems to have been an intentional nuisance). Note that Luthringer v. Moore, supra note 61 , discusses only Green v. General Petroleum Corp., supra note 71, cites only Munro v. Dredging etc. Co., supra note 73, and does not mention any of the other cases cited in notes 73-76 supra.

1 (1949) 33 A. C. 471,202 P. (2d) 1018.

2 (1948) 298 N. Y. 135,81 N. E. (2d) 54.

3 Restatearent, Property $\$ 314$ Comment $h$ (1940); 1 ScotT, Trusts $\$ 127.1$ (1st ed. 1939) ; 1 SIMTE, FuTURE INTERESTS $\$ 146$ (1st ed. 1936).

41 ScorT, op. cit. supra note $3, \S 127.1 ; 1$ SInres, op. cit. supra note $3, \S 146$. 
(3) Where, upon the settlor's death, federal taxing authorities seek to include an interest in the trust assets in the estate of the settlor, on the theory that a reversion has been retained. ${ }^{\mathbf{5}}$

5 At the very least, the value of the reversionary interest-if one is retained-is includible in the settlor's gross estate under section 811 (a) of the Internal Revenue Code.

In one type of situation, however, if a reversion is found, the entire trust estate must be included in the settlor's gross estate under section 811 (c). If the trust creates interests such that "(1) possession or enjoyment of the transferred interest can be obtained only by beneficiaries who must survive the decedent, and (2) the decedent or his estate possesses any right or interest in the property," the value of those interests is includible in the settlor's (decedent's) gross estate. Estate Tax Regs. 105, § 81.17. Example: A settlor creates a trust, with the income to be accumulated and added to corpus until his death, and the corpus to be paid on his death to his surviving children. The share of any child who predeceases the settlor shall be paid to his issue, or, if no issue survive the settlor, to other children of the settlor or their issue. If no children and no issue of any child survive the settlor, the corpus shall be paid to the settlor's heirs. If this limitation to the settlor's heirs is held to be a reversion, the entire trust estate is includible in the settlor's gross estate, even though the beneficiaries do in fact survive. In Estate of Spiegel v. Comm'r. (1949) 335 U.S. 701, the Supreme Court imposed a tax of $\$ 450,000$ due to the retention of a remote reversion (worth only $\$ 70$ ) through an incomplete disposition (as found by the circuit court of appeals), although the settlor apparently intended no reversion and existing state decisions left the existence of a reversion under the terms of the trust instrument in doubt. The Treasury has proposed amendments to Estate Tax Regulations 105, \$ 81.17, seemingly designed to clarify it in view of the Spiegel case. Estate Tax: Transfers Intended to Take Effect at or after Death, Notice of Proposed Rule Making, Department of Treasury, Bureau of Internal Revenue, 14 FED. REG. 1824 (1949). Example 6 of the proposed amendments states the facts of the example given above (except that the final limitation over is to "the next of kin" of the settlor, rather than to his heirs) and then states: "In this case, the decedent has parted with every right and interest in the property and hence requirement (2) is not satisfied. Accordingly, no part of the property is includible in the decedent's gross estate under this section." The amendment apparently takes it for granted that the limitation to the next of kin creates a remainder in them. It is doubtful if the example is intended to govern where, under apphicable state law, a reversion instead of a remainder is held to result, since then the decedent would not have "parted with every right and interest in the property." Such a reversion would be a remote reversion, quite comparable to that in the Spiegel case. (Even on the assumption that the limitation to the heirs creates a remainder, a "very remote" reversion still is present, as a failure of heirs is possible. If children, issue, and heirs all fail, the property will revert to the settlor's estate and be subject to the residual clause of his will. It must he assumed, however, that the Treasury here intentionally declines to pursue the logic of the Spiegel case to its ultimate extreme.)

The reservation of any power of appointment by will or deed, of course, is the retention of a "right or interest in the property," regardless of the existence of a reversion, and makes the entire corpus includible under Regulation 105, $\S 81.17$, if the other condition of $\S 81.17$ is met. Even if this condition is not inet, the value of the interests subject to the power must be included. INT. Rev. Cone $\$ 811$ (d). Likewise, if the settlor is himself the life beneficiary of the trust, the entire trust estate is includible whether or not a reversion exists. INT. REv. CODE $\S 811$ (c)(1). Coinm'r. v. Estate of Church (1949) 335 U.S. 632. (The Treasury's proposed amendments to Regulations 105, $\$ 81.17$, cited above, do not make trusts includible in the gross estate solely on the basis that a life estate in the settlor lias been reserved if such trusts were created prior to March 4, 1931, and the settlor died prior to the date of the Church decision. In these cases, construction of a limitation to heirs as a remainder or reversion is still a crucial question.)

To avoid the consequences of the Spiegel case, Minnesota, in March 1949 passed a statute providing that "if by the terms of the controlling trust instrument the settlor 
(4) Where the settlor applies to a court for a decree terminating the trust.

The problem arises most frequently in this last situation. A valid irrevocable trust will not be terminated unless all persons beneficially interested in the trust are represented before the court, are of full competency, and consent to the termination..$^{6}$ If a remainder is held to have been created, then under the generally prevailing rule the settlor's request for termination will be denied on the ground that a group of unascertained beneficiaries, such as the heirs of a designated living person, cannot be represented before the court or give their consent. ${ }^{7}$

\section{The rule against a remainder in the grantor's heirs as a rule of positive law and as a rule of construction}

At common law, if an owner of land in fee simple sought to convey a life estate, with a remainder to his heirs, the limitation to the heirs was void, and the grantor retained a reversion in fee. ${ }^{8}$ This rule against a remainder in the grantor's heirs-sometimes erroneously termed

manifested irrevocably his intention to divest himself of all interest in said trust property," an otherwise reversionary interest in the settlor should be deemed held upon a resulting trust for the State of Minnesota. Minnesota Laws of 1949, Chapter 201.

6 Restatement, Trusts $\S \S 338,340$ (1935); 3 Scott, op. cit. supra note $3, \S 340$. Gray v. Union Trust Co. (1915) 171 Cal. 637, 154 Pac. 306; Fletcher v. Los Angeles Trust etc. Bank (1920) 182 Cal. 177, 187 Pac. 425; Estate of Easterday (1941) 45 Cal. App. (2d) 598, 114 P. (2d) 669.

7 Restatement, Trusts $\$ 340$ comment $d$ (1935); 3 Scott, op. cit. supra note 3 , § 340. New York provides by statute (N. Y. Personal Property Law $\S 23 ;$ N. Y. Real Property Law $\$ 118$ ) that the creator of a trust may revoke it "upon the written consent of all the persons beneficially interested" in the trust. As construed by the lower courts this statute permits a settlor to procure termination of a trust with the consent of those beneficiaries, if any, in being at the time of the termination. Aranyi v. Bankers' Trust Co. (1922) 201 App. Div. 706, 194 N. Y. Supp. 614; Note (1938) 51 Harv. L. REv. 754. In Engel v. Guaranty Trust Co. of New York (1939) 280 N. Y. 43, 19 N. E. (2d) 673 , where a remainder for settlor's heirs was created, the court of appeals held that though it might not be necessary under the statute to obtain the consent of unborn persons, it was necessary to obtain the consent of all living persons who might ultimately prove to be the settlor's heirs on his death. Since such a class of persons is unascertainable, it was, of course, impossible to get the consent required.

In California, without the aid of statute, the district court of appeals in Mabry v. Scott (1942) 51 Cal. App. (2d) 245, 124 P. (2d) 659, held that under the doctrine of "virtual representation" unborn contingent remaindermen may be adequately represented by the persons holding the preceding estate in a suit for cancellation of a trust. It might not be an undue extension of the doctrine to hold that in the case of a limitation to the heirs of the settlor, all persons who will ultimately prove to be the heirs of the settlor on his death may be adequately represented, in a suit for termination, by those who would be his heirs if he died at the time of the attempted termination, there being no hostility of interest within the class of heirs. This would be contrary to the result reached by the New York Court of Appeals in the Engel case.

In his dissent in Moxley v. Title Ins. \& Trust Co. (1945) $27 \mathrm{Cal}$. (2d) 457, 477, $165 \mathrm{P}$. (2d) 15, Justice Traynor advanced the conclusion that where unborn children are represented by a guardian ad litem and their rights adequately safeguarded, an equity court has inherent power to terminate a trust as to their interests.

81 SIMEs, op. cit. supra note $3, \S 144$. 
the doctrine of worthier title - was a rule of positive law, like the rule in Shelley's case; that is, it applied wholly without reference to the settlor's intent, however clearly expressed, and denied his power to create such an interest in his heirs. As the common law rule had its origin in the law of feudal tenure, the reasons for the rule, ${ }^{10}$ of course, have long since disappeared.

By contrast, under modern authorities the question is solely one of construing the grantor's-or, in the case of a trust, the settlor'sintent, gathered from the terms of the instrument. If the grantor manifests an intent to create a remainder in his heirs, no good reason requires its frustration and the gift to the heirs will be given effect. The problem is, then, to formulate a satisfactory rule of construction which will accord with the intent of the typical settlor.

By assumption, in the question under discussion, the instrument in terms gives a remainder to the heirs. Why should this not be literally construed, as language in a grant normally is? Is there any reason why the plain language of the limitation should be ignored? The answer must be that it is inherently improbable that a settlor should, to use Professor Edward H. Warren's words, "intend to strip himself of control, to arm his prospective heirs and next of kin against himself, and to create in them, to his own possible embarrassment, indestructible future interests." 11 As Dean Griswold says, a man would rarely be "so blind in his generosity that he would intend to make a present gratuitous conveyance of an interest in his property to persons whose identity would not be determined until his death."12 Why, then, it might be asked, did the settlor use such language? Professor Warren suggests a convincing answer. What appears on its face as a gift to heirs is but an artless attempt by the settlor to express a reversion. Thus, where the settlor is to enjoy the property for life, it will seem natural to him to provide that if the property is to "come

\footnotetext{
${ }^{9}$ Under the doctrine of worthier title, if a testator devised to an heir the precise interest in land which he would have inherited in the absence of a will, the heir was regarded as taking the land by descent rather than by devise; the former was considered the "worthier title." The heir was certain to take; the question was simply as to the nature of his title. The rule against a remainder in the grantor's heirs, on the other hand, applies only to inter vivos conveyances; the question is whether the heir takes an interest at all. The doctrine of worthier title applied even though the will specifically named the heir; the rule against a remainder applied only to class gifts to "heirs," and never applied to grants of remainders to named persons. I Srares, op. cit. supra note $3, \S \S 144,145$. The description of the rule against a remainder as a rule of worthier title apparently originated in the Restatement of Property. See $\$ 314$, comment $(a)$, and also Warren, $A R E$ mainder to the Grantor's Heirs (1943) 22 TEx. L. REv. 22, 26-28.

10 The purpose of the rule apparently was to eliminate a device attempted by tenants in fee to evade the feudal burdens. SIMEs, op. cit. supra note $3, \$ 146$. In 1833 the common law rule was abolished in England by statute ( $3 \& 4$ Wnd. IV, c. 106, \$ 3) and a grantor's heirs unay now take as purchasers. Ibid.
}

11 Warren, Book Review (1938) 2 Toronto L. J. 389, 391.

12 Grisword, Spendthriet Trusts 545, n. 21 (1947). 
back" at his death (or at a date later than his death) it shall come back, not to him, a dead man, but to his heirs or next-of-kin,-meaning his estate. ${ }^{13}$ Likewise, even where the settlor does not reserve enjoyment during his life but gives a life interest to a benficiary, or successive life interests to beneficiaries, whom he in fact expects to survive him, it will seem pointless and unrealistic to provide that the property shall "come back" to him, as he expects then to be dead; there again it will be natural to provide that the property shall "return" to his heirs.

Thus, although the feudal grounds for the rule against a remainder in the grantor's heirs no longer exist, American courts have, with good reason, continued it as a rule of construction. ${ }^{14}$ Doctor $v$. Hughes ${ }^{15}$ is the leading case in point. There Justice Cardozo, speaking for the New York Court of Appeals, stated that "at least the ancient rule survives to this extent, that to transform into a remainder what would ordinarily be a reversion, the intention to work the transformation must be clearly expressed." "Under such a rule, the settlor has the power to create a remainder in his heirs if he wishes, but must make his intent clear so as to overcome the constructional preference in favor of a reversion; unless such intent is clearly shown, the rule will disregard the limitation to the heirs, leaving a reversion in the settlor. This result will effect the settlor's probable intent in the vast majority of cases.

The doctrine of Doctor $v$. Hughes establishes a rule of construction derived from the coinmon law rule, and is therefore presumably coextensive with it in scope; it applies to limitations to heirs, i.e., those who will take the settlor's intestate property upon his death. Should the rule be extended to limitations to so-called "artificial" classes of heirs, e.g., to "heirs" determined by reference to either an artificial "time of death" or an artificial law of succession? It is arguable that here also the settlor did not intend to surrender control; the variation is perhaps a naive attempt to combine in one instrument an inter vivos transfer and a testamentary disposition. The settlor, however, clearly

13 Warren, Book Review (1938) 2 Toronro L. J. 389, 391.

14 But compare Nossaman, Gifts to Heirs-Remainder or Reversion (1949) 24 CALIF. S. B. J. 59, 62." . . . it is believed that the reversionary rule . . . represents an anomalous survival of a feudal rule, erroneously revived in America by courts and text writers as a rule of construction long after it bad ceased to have meaning as a rule of law; that it cannot afford an indication of intent for the very reason tliat historically it applied regardless of intent and finally, that both in popular and in legal parlance, 'heirs' does not inean 'estate'." Nossaman fails to mention the inain justification of the reversionary rule of construction, namely, that a literal construction of the limitation would prohably defeat the typical settlor's intent. See text, supra at notes 12 and 13.

15 (1919) 225 N. Y. 305, 122 N. E. 221.

10 Id. at 312,122 N. E. at 222 . Compare the Restatement's phrasing: “... unless a contrary intent is found from additional language or circumstances . . . ." RestateAIENT, PROPERTY $\$ 314(1)$. Comment (e) makes it clear that extrinsic circumstances cannot be considered. 
was unwilling to accept all the incidents of a reversion; if this is true, the intent to reserve a reversion which alone justifies disregarding the plain language of the limitation is not present, so the basis for the application of the rule is wanting.

What is the California law on this point? In Gray v. Union Trust Co. ${ }^{17}$ a remainder was limited to "heirs at law, according to the laws of succession of the State of California as such laws now exist." The supreme court held the heirs took a remainder, pointing out that the class specified might differ from the statutory heirs if the law of succession were changed prior to the settlor's death. Likewise, in Bixby v. Hotchkis ${ }^{18}$ the district court of appeal seemingly held that where the limitation is to the settlor's heirs to be determined in accordance with the laws of succession in effect at a fixed time of distribution, other than and subsequent to the date of the settlor's death, a remainder is created in such persons.

The Restatement, too, limits the rule to cases where the gift is to the heirs or next-of-kin of the settlor in the statutory sense. ${ }^{19}$ The New York Court of Appeals, on the other hand, recently applied the rule of Doctor v. Hughes to a limitation to an artificial class of heirs. ${ }^{20}$

It has been suggested that the rule of Doctor v. Hughes might not

1r (1915) $171 \mathrm{Cal} .637,154 \mathrm{Pac}$. 306. An alternative ground of decision rested upon a construction of Civil Code section 779. See text, infra at note 45.

18 (1043) 58 Cal. App. (2d) 445, 136 P. (2d) 597, hearing denied, three judges dissenting. In this case the settlor created a 20 year trust, for the benefit of himself, and then provided: "Upon the expiration of the term of this trust, hereinafter specified, to-wit, a period of twenty (20) years from the date hereof, my trustee shall distrihute ... my trust estate ... in the manner following: (a) The whole thereof to me personally if I be hiving at the time. (b) In the event that I should die prior to the expiration of said period the whole there of to my heirs at law in accordance with the laws of succession in the State of Califoruia then in effect." (at page 449) (Emphasis added). Does "then in effect" refer to the time of the settlor's death, or to the time of distrihution? The court's opinion simply speaks of "heirs at law" without mentioning any distinction between statutory heirs and an artificial class of heirs. Apparently the court either interpreted the language to refer to statutory heirs (its normal ineaning) or else attached no legal significance to the distinction. In either event, then, in finding a remainder the court inplicitly rejected the rule against a remainder in the grantor's heirs. In Bixby v. California Trust Co., supra note 1 , however, the supreme court (1) stated that the Bixby $v$. Hotchkis court "construed this provision to mean that the heirs were to be determined according to the law at the end of the 20-year period" (at 475) and (2) distinguished the case on that ground.

19 Restatement, Property \& 314, comment (c) (1940).

20 Matter of Scholtz v. Central Hanover Bank \& Trust Co. (1946) 295 N. Y. 488, 68 N. E. (2d) 503, noted in (1946) $60 \mathrm{HARv}$. L. REv. 147. Accord: Julier v. Central Hanover Bank \& Trust Co. (1947) 272 App. Div. 598, 74 N. Y.S. (2d) 262, appeal denied, 297 N. Y. 1036, 78 N. E. (2d) 869 . (In the Scholtz case, the court did not expressly take note of the fact that it was applying the rule to an artificial class. In Richardson v. Richardson, supre note 2, the court cited these cases, with apparent approval, as holding the rule apphed to natural and "artificial" heirs without distinction.) Dunnett v. First Nat. Bank \& Trust Co. of Tulsa (1938) 184 Okla. 82, 85 P. (2d) 281. But cf. Schoellkopf v. Marime Trust Co. of Buffalo (1935) 267 N. X. 358, 196 N. E. 288.

See also text infra at note $\mathbf{5 0 .}$ 
apply where the settlor has disposed of the immediate beneficial interest, e.g., by giving a life interest to a third party, on the theory that, having parted with possession and enjoyment, the settlor is more likely to have intended surrender of control as well..$^{21}$ Since the settlor reserved no life interest, a reversion might conveniently have been directly reserved to him, a living person, and the explanation of the remainder as an ineptly expressed reversion is less plausible. ${ }^{22}$ Such a distinction, moreover, might in some cases have advantageous tax consequences to settlors. ${ }^{23}$ The weight to be attached to a surrender of present enjoyment as indicative of a surrender of all control is debatable; a settlor may well surrender the former and desire to retain the latter. In the typical trust, moreover, which provides life interests in third parties, the settlor expects those life beneficiaries to survive him, and therefore does not in fact expect a return of the property during his life; here too, not implausibly, he may intend a reversion by providing for a return to his heirs. ${ }^{24}$ No cases make the suggested distinction. ${ }^{25}$

\section{The New York rule of construction}

Because of the dearth of California authority on the subject of this comment, courts and lawyers no doubt will refer to the case law developed in New York, where the rule against a remainder in the grantor's heirs as a rule of construction was first clearly announced. There they will find the case history of a sound rule twisted and frustrated by over-refinements and over-subtle distinctions.

Doctor v. Hughes laid down a rule of constructional preference and, to overcome it, required that an intention to create a remainder be "clearly expressed." Does this mean the intent must appear by express-i.e., explicit- statement, ${ }^{26}$ or may it be "expressed" by clear implication? Despite valid arguments for the former interpretation, ${ }^{27}$ the New York court adopted the latter, and then proceeded to apply it in such circumstances as to render the requirement of "clear expression" virtually meaningless.

The process began with Whittemore v. Equitable Trust Co. $^{28}$ There a settlor created a trust for the life of a third party beneficiary. On the life beneficiary's death, the trustee was directed: (a) to pay the principal to the settlor if he were alive, (b) if he were dead, to

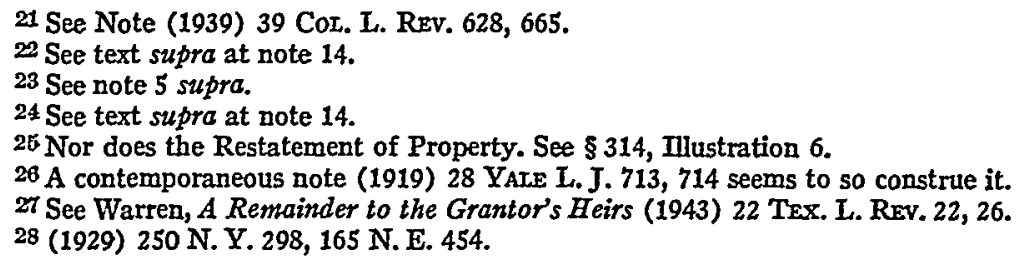


pay it as directed in the settlor's will, or (c) if the settlor left no will, to pay it to those persons who would then take under the laws of succession. The lower courts found a reversion. The court of appeals reversed; purporting to follow Doctor v. Hughes, it nevertheless found a "clear expression" of an intent to create a remainder in that the settlor made a "rather full and formal disposition of the principal" 20 in case he died before the life beneficiary, and reserved a power of disposition by will only. Similar cases followed. ${ }^{30}$ In 1948 the court of appeals, in Richardson $v$. Richardson, ${ }^{31}$ exhaustively reviewed the New York decisions, approved them, and summarized their holdings by listing the following factors whose presence tended to indicate an intent to create a remainder:

"(1) that the settlor has made a full and formal disposition of the corpus of the estate, i.e., disposed of the principal on several contingencies other than having it revert to himself,

(2) that the settlor has made no reservation of a power to grant or assign an interest in the property in his lifetime, ...

(3) that he has reserved only a testamentary power of appointment" and

(4) that the settlor has failed to provide for the return of the principal or any part thereof to himself upon any contingency. ${ }^{32}$

The joint presence of the first three factors seemingly establishes as a matter of law an intent to create a remainder; it is not clear, however, what weight is accorded each factor, nor whether the presence of but several of the factors permits, or requires, the court to find such intent.

Are any of these factors convincing? The meaning of the first- " a full and formal disposition"-is not clear. The court's amplification of this term-disposition "of the principal on several contingencies"seems to suggest that the "fullness" or completeness of the disposi-

$29 \mathrm{Id}$. at $303,165 \mathrm{~N}$. E. at 456.

30 Hussey v. City Bank Farmers Trust Co. (1932) 236 App. Div. 117, 258 N. Y. Supp. 396, aff'd 261 N. Y. 533, 185 N. E. 726; Schoellkopf v. Marine Trust Co. (1935) 267 N. Y. 358, 196 N. E. 288 ; Engel v. Guaranty Trust Co. (1939) 280 N. Y. 43, 19 N. E. (2d) 673 (remainder found). Cf. City Bank Farmers Trust Co. v. Miller (1938) 278 N. Y. 134, 15 N. E. (2d) 553; Scholtz v. Central Hanover Bank \& Trust Co., supra note 20; Julier v. Central Hanover Bank \& Trust Co., supra note 20; Berlenbach v. Chemical Bank \& Trust Co. (1932) 235 App. Div. 170, 256 N. Y. Supp. 563, aff'd (1932) 260 N. Y. 539, 184 N. E. 83; Davies v. City Bank Farmers Trust Co. (1936) 248 App. Div. 380, 288 N. Y. Supp. 398 (reversion found). For further New York cases, see Note (1939) 39 Cor. L. Rev. 628, 662.

31 Supra note 2. In this case tlie settlor (life beneficiary) provided that upon his death the corpus was to be distributed to his appointees by will, in default of appointment to his mother if living, and if she were dead, to his distributees under New York law. The settlor made no provision for the return of any part of the corpus during his lifetime.

32 Id. at ......., 81 N. E. (2d) at $56,59$. 
tion $^{33}$ is tested by its complexity, i.e., the number of alternative dispositions preceding the gift to the heirs. ${ }^{34}$ Is there any valid reason to thus distinguish between simple and complex dispositions, that is, between unconditional gifts to heirs limited only on the death of the life beneficiary and gifts to heirs conditional on failure of one or more antecedent alternative dispositions? None appears. The explanation why a settlor might express an attempted reversion by a limitation to his heirs, set forth above, ${ }^{35}$ applies with equal force to both. A complexity test may easily degenerate into one of simple counting; otherwise it will necessarily be productive of fine distinctions and therefore become unworkable.

The third factor-reservation of power of appointment by will only-is perhaps the most stressed, but likewise appears unconvincing. ${ }^{36}$ The argument is that a settlor would not reserve a testamentary power of appointment whose exercise would "defeat" the expressed remainder unless he believed he had created an interest in the heirs, since otherwise the reservation would be superfluous. The proponents of this argument are perhaps unconsciously influenced by the traditional classification in the law of future interests of gifts subject to a power. Since gifts in default of appointment (not otherwise contingent) are traditionally treated as vested interests subject to divestment by exercise of the power, ${ }^{37}$ a tendency may well exist to construe a disposition of the type "as I shall appoint by will, and, in default of appointment, to my heirs" as a present gift to the heirs, subject only to a power of defeasance. Realistically, however, the grantor-con-

33 The Restatement of Property likewise accepts the "completeness" test. It does not define the term, but gives an illustration based on the facts of the Whittemore case and states: "The completeness of the plan of the conveyor indicates that the gift to his heirs is to them as purchasers ..." Restatement, Property $\S 314$, comment (e), Illustration 5 (1940).

34 It is not clear from the opinion that the court actually means to define "full and formal disposition" by paraphrasing it as a disposition of corpus "on several contingencies other than having it revert to himself." Later in the opinion, the court refers to the Hussey case (supre note 30 ) and says the court there ". . . again gave much weight to the fact that there was a coinplete disposition of the trust estate with a vested remainder to the next of kin of the settlor which might be divested by the will of the life beneficiary but could not be divested by grant or assignment." Richardson v. Richardson, stupra note 2 at ......., 81 N. E. (2d) at 57.

If by this the court means the disposition was complete because a vested remainder was created, it of course completely begs the question.

35 See text supra at note 14.

36 The Restatement of Trusts takes the position that where the settlor has omitted to reserve a power to appoint in any way except by will, this fact is "some indication that he intended to make his heirs or next of kin beneficiaries . . . but it is not of itself sufficient to overcome the inference that lie intended to be sole beneficiary of the trust." Restatenent, Trusis $\$ 127$, comment (a) and Illustration No. 2 (1935). The Restatement of Property apparently adopts the same position. See Restatement, Property, Notes to THE MEATBers of THE INSTITUTE, \$ 314 (Tent. Draft No. 11, 1939).

871 SnOEs, op. cit. supra note $3, \S 80$. 
templating the possibility of a "return" of the property after his death - simply spells out the incidents of a reversion, by providing that, if he die testate, the property shall pass according to his will, and, if he die intestate, according to the laws of intestacy. ${ }^{38}$

Certainly no significance should be attached to the second and fourth factors-the settlor's failure to reserve a power to assign an interest in the property during his life, and the failure to provide for a return upon some contingency of any part of the principal-by any court purporting to follow Doctor v. Hughes. The second factor limits the rule of Doctor $v$. Hughes to situations where the settlor has expressly reserved a power to assign the principal, that is, to situations where the question of the existence of a reversion is purely academic since then the settlor has, in effect, full control anyway. To attach weight to the fourth factor seems unjustifiable. A provision for a return of principal on some contingency would, no doubt, under reasoning like that advanced for the third factor, have been held evidence of an intent to create a remainder. ${ }^{39}$ To prove the same intent by the absence of such a provision seems a "heads I win, tails you lose" device.

The net effect of the present New York rule is to reverse the constructional preference laid down in Doctor v. Hughes, and to require express mention of the incidents of a reversion to avoid the creation of a remainder. The rule, moreover, seems unworkable, burdened as it is with complications and uncertainties. ${ }^{40}$ The difficulties experienced by the lower New York courts in applying it are shown by the fact that most pertinent court of appeals decisions since the Whittemore case have been reversals of lower court holdings; ${ }^{41}$ thus every case is a potential "court of appeals" case.

The nightmarish development of the New York law was perhaps what prompted the draftsmen of the Uniform Property Act to abolish

\footnotetext{
${ }^{38}$ Nossaman believes that "the reservation of such a power [i.e., to appoint by will] approaching full ownership ... " makes "a case far stronger for [a] reversion ...." Nossaman, Gifts to Heirs-Remainder or Reversion, supra note 14, pp. 61-62.

Thus, for example, under the facts of the Whittemore case, few laymen would suppose that a settlor, by reserving so much control, would thereby irrevocably surrender an interest in the property to his heirs.

39 The court of appeals did just this in the Engel case, supra note 30 . The court there found that a reservation of a power to withdraw corpus up to $\$ 15,000$ was evidence of "the purpose of the grantor to fully divest himself of any other reversionary interest ...."Id. at 47,19 N. E. (2d) at 674.

40 Nossaman attributes "the almost intolerable confusion" of the present New York case law to Doctor v. Hughes. Nossaman, Gifts to Heirs-Remainder or Reversion, supra note 14 at 62 . This comment has attempted to show that the confusion is due to the fact that the New York Court of Appeals, in the Whittemore and subsequent cases, (1) held the requirement of "clear expression" of intent satisfied by implications from dispositive provisions of the instrument, and (2) sought and "found" far-fetched implications of such intent.

41 E.g., City Bank Farmers Trust Co. v. Miller, supra note 30; Engel v. Guaranty Trust Co., supra note 30; Scholtz v. Central Hanover Bank \& Trust Co., supra note 20; and Richardson v. Richardson, supra note 2.
} 
the rule against a remainder in favor of one giving literal effect to grants of remainders to heirs. ${ }^{42}$ This, however, is too drastic a solution, wholly inconsistent with the modern policy of effecting the grantor's intent, if workable alternatives exist.

\section{Remainders to settlor's heirs in California}

The legal effect of a limitation of a remainder to the settlor's heirs as determined at the settlor's death was first squarely presented to the California appellate courts in Bixby v. California Trust Co ${ }^{43}$ Plaintiff settlor sought to terminate an irrevocable spendthrift trust under which he was to receive the income for life and on his death "all the residue and remainder" was to be distributed to his heirs at law in accordance with the laws of succession then in effect. Since plaintiff's right to termination was conceded if he was the sole beneficiary, the precise question in the case was whether such a disposition created an interest in the heirs or merely resulted in a reversion. The trial court concluded a remainder was created and refused termination. The district court of appeal affirmed, ${ }^{44}$ holding the case governed by Civil Code section 779, as construed by the supreme court in Gray v. Union Trust Co. Section 779 abrogates the rule in Shelley's case; an alternative holding in the Gray case-set forth somewhat casually at the end of the opinion ${ }^{45}$ - construed it as operating in every case to change the term "heirs" from a word of limitation to a word of purchase. The district court of appeal thought this construction rendered the rule against a remainder to a grantor's heirs inapplicable in California. This construction of section 779 was clearly erroneous, as the

42 The Uniform Property Act, $\$ 15$, provides that the heirs take as purchasers. This act was drafted by the American Law Institute in cooperation with the Commissioners on Uniform State Laws.

Some advocates of the Uniform Property Act apparently assune, without discussion, that the reasons for abolishing the worthier title doctrine are similarly apphicable to the rule against a remainder in the grantor's heirs. See Foster, Some Observations on the Uniform Property Act (1941) 20 NEB. L. Bull. 333, 338; Myerberg, Maryland Examines the Proposed Uniform Property Act (1939) 4 MD. L. Rev. 1, 32, 33. But cf. Notes and Legis. (1939) 52 HARv. L. Rev. 993, 1000.

43 Supre note 1 . The question also arose in the companion case of Nelson v. California Trust Co. (1949) 33 A. C. 477, 202 P. (2d) 1021 involving the identical trust. It is interesting that the same district court of appeal which in the Bixby case held that a remainder was created in the heirs, speaking through another division, held in the Nelson case (198 P.(2d) 66) that the settlor was the sole beneficiary and that therefore his judgment creditor could rcach the principal of the trust. The supreme court affirmed, holding that in accordance with the general rule where the settlor is himself the beneficiary spendthrift provisions are invalid.

The Gray case, supra note 17, involved a himitation to an "artificial" class of heirs. Bixby v. Hotchkis, as pointed out in note 18 , on its facts quite possibly did present the question, and, quite possibly, the court in that case meant to answer it. The present ease of Bixhy v. Cahfornia Trust Co., however, interprets the Bixby v. Hotchkis case as involving a limitation to an "artificial" class, similar to the Gray case. See note 18 supro.

44 (1948) 190 P. (2d) 321.

45171 Cal. 637 , at 648,154 Pac. at 311. 
section refers in terms only to limitations to heirs "of a person to whom a life estate in the same estate is given" and does not cover limitations to the heirs of a grantor; it is generally recognized that statutes abolishing the rule in Shelley's case have no application to such limitations. ${ }^{46}$ The district court of appeal, however, felt itself bound by the Gray case.

The supreme court, pointedly omitting any mention of section $779,{ }^{47}$ reversed in a short opinion, stating:

When the trust instrument specifies that the income shall be paid to the trustor for life and provides that on his death the trust property shall be distributed to his heirs at law, it is generally held that no remainder interests are created and that the trustor is the sole beneficiary and retains a reversionary interest in the trust corpus. [citations $^{48}$.

The rule established by the above decisions has been justified upon the theory that such a result carries out the usual intention of the trustor, and it applies unless a contrary intent is manifested....

In the present case there is nothing which shows an intent on the part of plaintiff to create remainder interests in his heirs at law or to justify a departure from the usual rule of construction. Accordingly, the trial court erred in construing the trust instrument as creating such interests.

Defendant contends that the cases of Gray v. Union Trust Co.... and Bixby v. Hotchkis ... are in conflict with this conclusion. These cases, however, are distinguishable. . . .49

Justice Carter, in a concurring opinion, urged that the court 46 I Sraces, op. cit. supra note $3, \S 148$. Doctor v. Hughes, supra note 15 at 309 , 122 N.E. at 221.

47 And thereby, by necessary implication, repudiating the construction of section 779 set forth in the Gray case.

48 In support of this proposition the court cites a number of cases from various jurisdictions. These include: (a) a set of cases apparently based on the common law rule against a remainder, a rule of property: Burton v. Boren (1923) $308 \mathrm{Mll} .440,139$ N. E. 868; Fidelity \& Columbia Trust Co. v. Wilhams (1937) $268 \mathrm{Ky} .671,105 \mathrm{~S}$. W. (2d) 814; Dunnett v. First Nat. Bank \& Trust Co. (1938) 184 Okla. 82, 85 P. (2d) 281; (b) Doctor v. Hughes, supra note 15 ; (c) two cases apparently based upon the Restatements of Trusts and Property: Fidelity Umion Trust Co. v. Parfner (1944) 135 N. J. Eq. 133, 37 A. (2d) 675 ; Bottimore v. First \& Merchants Nat. Bank (1938) 170 Va. 221, 196 S. E. 593. In view of the different theories relied upon, it is difficult to determine the court's meaning when it speaks, in the next paragraph, of "the rule established by the above decisions." (Emphasis added.)

49 Bixby v. California Trust Co., supra note 1 at 473,202 P. (2d) at 1019. See note 43 supra.

The trust in the Bixby case was expressly declared irrevocable. By stating that sthere is nothing which shows an intent ... to create remainder interests in his heirs at law" the court necessarily lield this factor immaterial. Accord: Berlenbach v. Chemical Bank \& Trust $\mathrm{Co}_{0}$, supra note 30 . This seems a sound position. A declaration of irrevocability expresses an intent to be bound by the disposition made but does not seem relevant to the question of the extent to which a disposition has heen made.

Particularly is this true in California where an express declaration of irrevocabihty is required if the trust is to be irrevocable. CaI. Crv. CoDE $\$ 2280$. 
overrule Gray v. Union Trust Co. and Bixby v. Hotchkis, thus repudiating the distinction based upon the ascertainment of the heirs as of a date other than the settlor's death, and place its decision on the "sounder ground" that the rule of construction adopted increases alienability. ${ }^{50}$

Since the leading opinion carefully limits its holding to the facts of the case, the status of other, more complex, conveyances containing himitations to the settlor's heirs remains unsettled. It is impossible to say whether the Califorma courts will be influenced by the New York case law or will steer clear of its intricacies. Yet it is precisely the complex conveyances which are of great practical importance, because they are far more common. Apart from the narrow point decided in the Bixby case and the indication that the literal wording of the grant alone will not govern, the opinion of the supreme court does not reveal the existence in California of any general rule of construction governinging limitations to settlors' heirs. The existing uncertainty has serious repercussions in the fields of trust termination, creditors' rights, and estate taxation, and should not be permitted to continue until resolved piecemeal by future litigation. As the history of the New York law indicates, moreover, the growth of case law, in this field at least, does not necessarily clarify the governing legal principle nor promote predictability. It is therefore believed that legislative action, enunciating a simple, clear cut rule, is desirable.

\section{Proposed statute}

A tentative draft of a remedial statute is set forth below. The proposed solution is to codify the rule against a remainder in the grantor's heirs as a rule of construction, and to require explicit words to overcome the constructional preference in favor of a reversion. ${ }^{51}$ In a narrow class of cases this constructional preference may result in adverse tax consequences. ${ }^{52}$ The policy of effecting the probable intent of typical settlors and of facilitating termination of trusts, however, seems of greater importance than tax disadvantages in a few cases. It will be noted that, consistently with the Gray case, limitations to artificial classes of heirs are not within the scope of the statute.

50 Id. at 475, 202 P. (2d) at 1020. But compare Nossaman, Gifts to Heirs-Remainder or Reversion, supra note 14 at 63. "It is believed that no 'policy' requires the result in the Bixby case. No policy can require alienability witbin time limits during which the statute says inalienability is lawful." The main reason for the rule, however, on which it must stand or fall, is not that it promotes "alienability" but that it effects the average settlor's intent and protects bim from the unintended creation of indestructible future interests.

51 This enbodies the interpretation of Doctor v. Hughes mentioned supra in text at note 26.

52 See note 5 supra. Even here the settlor may probably avoid the unfavorable tax consequences by amending the trust so as to surrender the reversion or by selling his reversionary interest. 